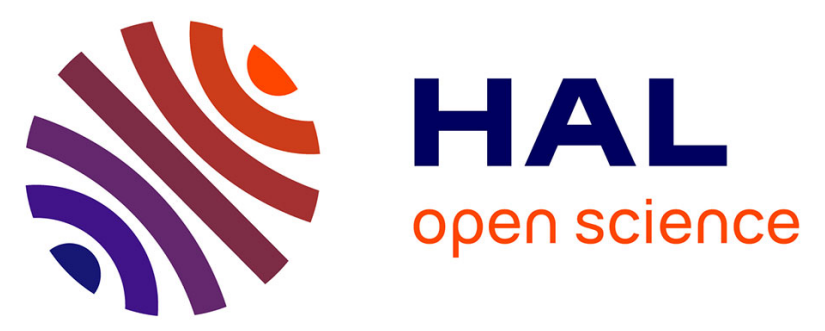

\title{
Phylogeny, biogeography and character evolution in the tribe Desmodieae (Fabaceae: Papilionoideae), with special emphasis on the New Caledonian endemic genera
}

Florian P Jabbour, Myriam P Gaudeul, Josie Lambourdière, Guillaume Ramstein, Alexandre A. Hassanin, Jean-Noël Labat, Corinne Sarthou

\section{To cite this version:}

Florian P Jabbour, Myriam P Gaudeul, Josie Lambourdière, Guillaume Ramstein, Alexandre A. Hassanin, et al.. Phylogeny, biogeography and character evolution in the tribe Desmodieae (Fabaceae: Papilionoideae), with special emphasis on the New Caledonian endemic genera. Molecular Phylogenetics and Evolution, 2018, 118, pp.108-121. 10.1016/j.ympev.2017.09.017 . hal-01677403

\section{HAL Id: hal-01677403 \\ https://hal.sorbonne-universite.fr/hal-01677403}

Submitted on 8 Jan 2018

HAL is a multi-disciplinary open access archive for the deposit and dissemination of scientific research documents, whether they are published or not. The documents may come from teaching and research institutions in France or abroad, or from public or private research centers.
L'archive ouverte pluridisciplinaire HAL, est destinée au dépôt et à la diffusion de documents scientifiques de niveau recherche, publiés ou non, émanant des établissements d'enseignement et de recherche français ou étrangers, des laboratoires publics ou privés. 


\title{
Phylogeny, biogeography and character evolution in the tribe Desmodieae (Fabaceae: Papilionoideae), with special emphasis on the New Caledonian endemic genera
}

\author{
Florian Jabbour ${ }^{\mathrm{a}}$, Myriam Gaudeul ${ }^{\mathrm{a}}$, Josie Lambourdière ${ }^{\mathrm{b}}$, Guillaume Ramstein ${ }^{\mathrm{a}}$, \\ Alexandre Hassanin ${ }^{\mathrm{a}}$, Jean-Noël Labat ${ }^{\mathrm{a}, \dagger}$, Corinne Sarthou ${ }^{\mathrm{a}, *}$ \\ a Muséum national d'Histoire naturelle, Institut de Systématique, Évolution, Biodiversité, UMR 7205 ISYEB MNHN/CNRS/UPMC/EPHE, Sorbonne Universités, 57 rue \\ Cuvier, CP 39, 75005 Paris, France \\ b Muséum national d'Histoire naturelle, Service de Systématique Moléculaire, UMS CNRS 2700, CP 26, 75005 Paris, France
}

\begin{abstract}
A B S T R A C T
The nearly cosmopolitan tribe Desmodieae (Fabaceae) includes many important genera for medicine and forage. However, the phylogenetic relationships among the infratribal groups circumscribed using morphological traits are still poorly known. In this study, we used chloroplast $(r b c L, p s b A-t r n H)$ and nuclear (ITS-1) DNA sequences to investigate the molecular phylogeny and historical biogeography of Desmodieae, and infer ancestral states for several vegetative and reproductive traits. Three groups, corresponding to the Desmodium, Lespedeza, and Phyllodium groups sensu Ohashi were retrieved in the phylogenetic analyses. Conflicts in the topologies inferred from the chloroplast and nuclear datasets were detected. For instance, the Lespedeza clade was sister to the groups Phyllodium + Desmodium based on chloroplast DNA, but nested within the Desmodium group based on ITS-1. Moreover, the New Caledonian endemic genera Arthroclianthus and Nephrodesmus were not monophyletic but together formed a clade, which also included Hanslia and Ohwia based on chloroplast DNA. The hypothetical common ancestor of Desmodieae was dated to the Middle Oligocene (ca. 28.3 Ma) and was likely an Asian shrub or tree producing indehiscent loments. Several colonization events towards Oceania, America, and Africa occurred (all less than ca. 17.5 Ma), most probably through long distance dispersal. The fruits of Desmodieae repeatedly evolved from indehiscence to dehiscence. We also showed that indehiscent loments allow for more variability in the number of seeds per fruit than indehiscent legumes. Modularity seems here to allow variability in the number of ovules produced in a single ovary.
\end{abstract}

\section{Introduction}

The tribe Desmodieae (Benth.) Hutchinson is an Old World tribe of the legume subfamily Papilionoideae. It includes many important genera used for medicine and forage. The tribe Desmodieae comprises 32 genera and ca. 530 species that mostly inhabit tropical, subtropical, and warm-temperate regions, but also extend into the cool-temperate and sub-boreal regions of Eastern Asia and North America (Ohashi, 2005; Ohashi and Ohashi, 2012a, 2012b). Two genera, Arthroclianthus Baill. and Nephrodesmus Schindl., are endemic to New Caledonia. The Desmodieae are commonly erect and trifoliate herbs, shrubs or rarely trees, with fruits either composed of a single article (a legume) or of several segments (a loment; Ohashi et al., 1981) (Fig. 1). The loment consists of a single carpel that disarticulates into single-seeded segments when ripe (Spjut, 1994). Fruit characters are of high taxonomical value in Desmodieae and in Papilionoideae as a whole (e.g. segmentation, dehiscence, size, pubescence, isthmus margin in loments; Kirkbride et al., 2003).

The Desmodieae have been once considered similar to tribe Phaseoleae (Polhill, 1981). They were subsequently shown to be a monophyletic group included within Phaseoleae sensu lato, and closely related to subtribe Kennediinae (Doyle and Doyle, 1993; Bruneau et al., 1995; Kajita et al., 1996; Doyle et al., 1997; Wojciechowski et al., 2004; Egan et al., 2016). A supertree using chloroplast DNA data (cpDNA; $r b c L, m a t K, t r n L$ intron; Lewis et al., 2005) placed the Desmodieae in the Millettioid/Phaseoloid clade, the single clade of the Papilionoideae subfamily characterized by a macromorphological apomorphy, pseudoracemose inflorescences (Wojciechowski et al., 2004). The

\footnotetext{
* Corresponding author.

E-mail address: corinne.sarthou@mnhn.fr (C. Sarthou).

${ }^{\dagger}$ Deceased author.
} 

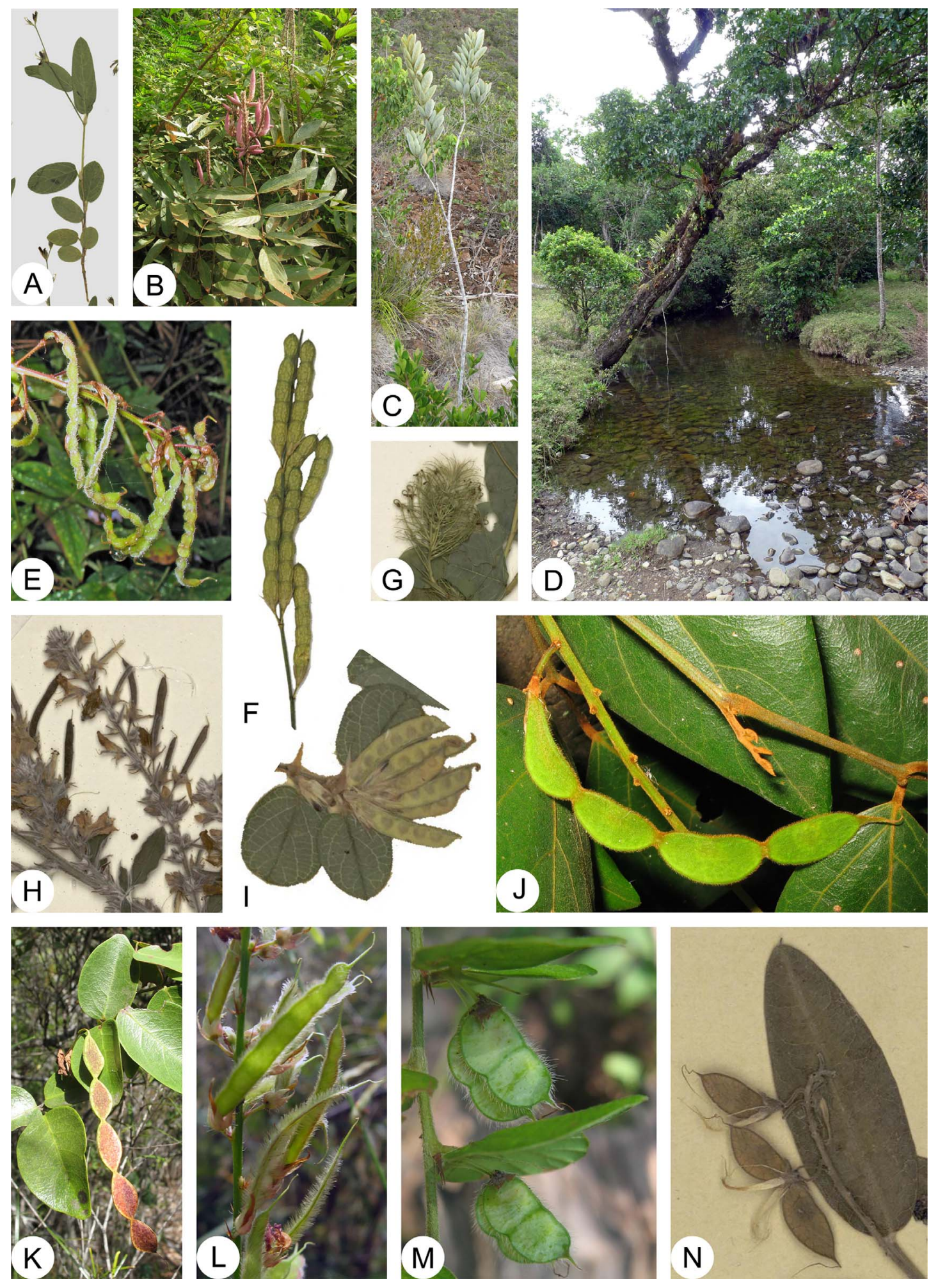

Fig. 1. Diversity of habits and fruit types in the tribe Desmodieae. (A) Herb: Alysicarpus ovalifolius (Desmodium group; one individual from the specimen Labat 3952, Paris Herbarium (P), barcode P00577613), (B) Subshrub: Uraria crinita (Desmodium group; credit: Sovanmoly Hul), (C) Shrub: Nephrodesmus sericeus (Desmodium group; credit: Jean-Noël Labat, Labat 3913 (P), P00609010), (D) Tree: Arthroclianthus angustifolius (Phyllodium group; credit: J.N. Labat), (E) Indehiscent loment: Desmodium intortum (Desmodium group; credit: J.N. Labat, Labat 3797 (P), P00527423), (F) Indehiscent loment: Alysicarpus ovalifolius (Desmodium group; fruits from the specimen Labat 3952 (P), P00758171), (G) Dehiscent legume: Mecopus nidulans (Desmodium group; fruits from the specimen Cheng, David \& Leti CL721 (P), P00625251), (H) Dehiscent legume: Pseudarthria hookeri (Desmodium group; fruits from the specimen Jongkind 2462 (P), P03496356), (I) Dehiscent legume: Melliniella micrantha (Desmodium group; fruits from the specimen Raynal-Roques 22514 (P), P03091983), (J) Indehiscent loment: Nephrodesmus francii (Phyllodium group; credit: J.N. Labat, Labat 3932 (P), P00609037), (K) Indehiscent loment: Arthroclianthus deplanchei (Phyllodium group; credit: J.N. Labat, Labat 3915 (P), P00609013), (L) Indehiscent loment: Tadehagi triquetrum (Phyllodium group; credit: S. Hul), (M) Indehiscent loment: Phyllodium pulchellum (Phyllodium group; credit: S. Hul), (N) Indehiscent legume: Campylotropis polyantha (Lespedeza group; fruits from the specimen Soulié 3968 (P), P03089856). 


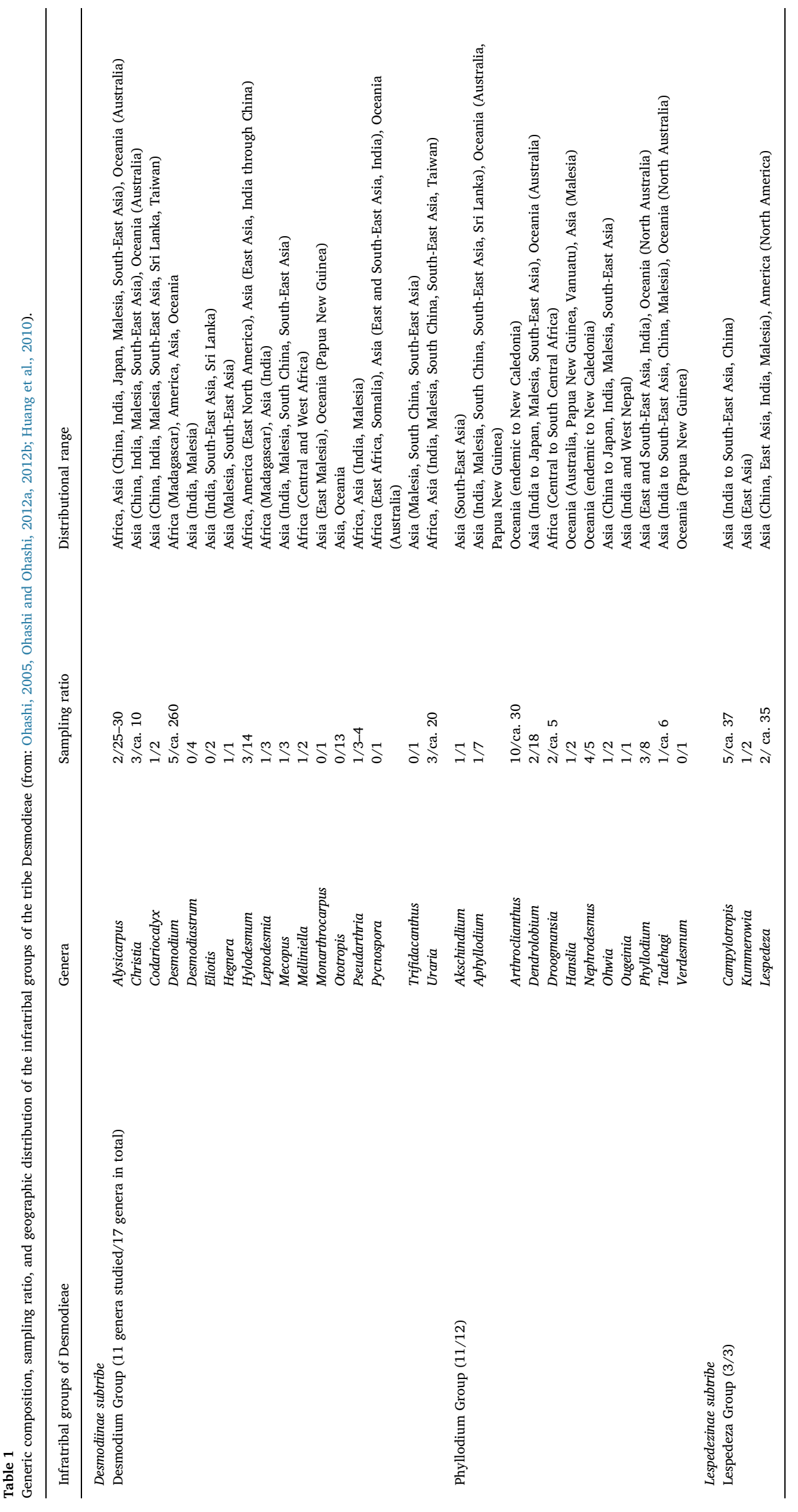




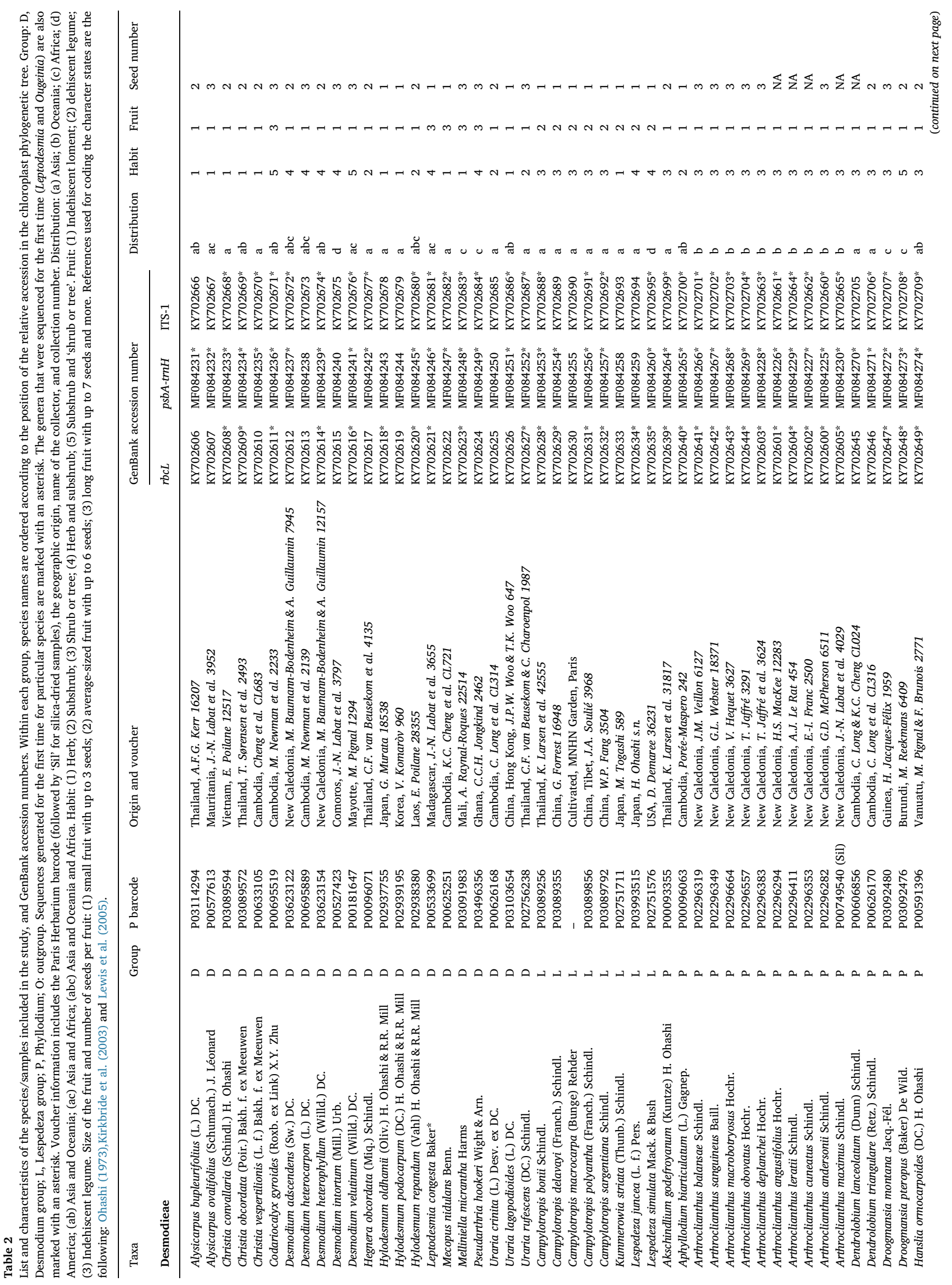




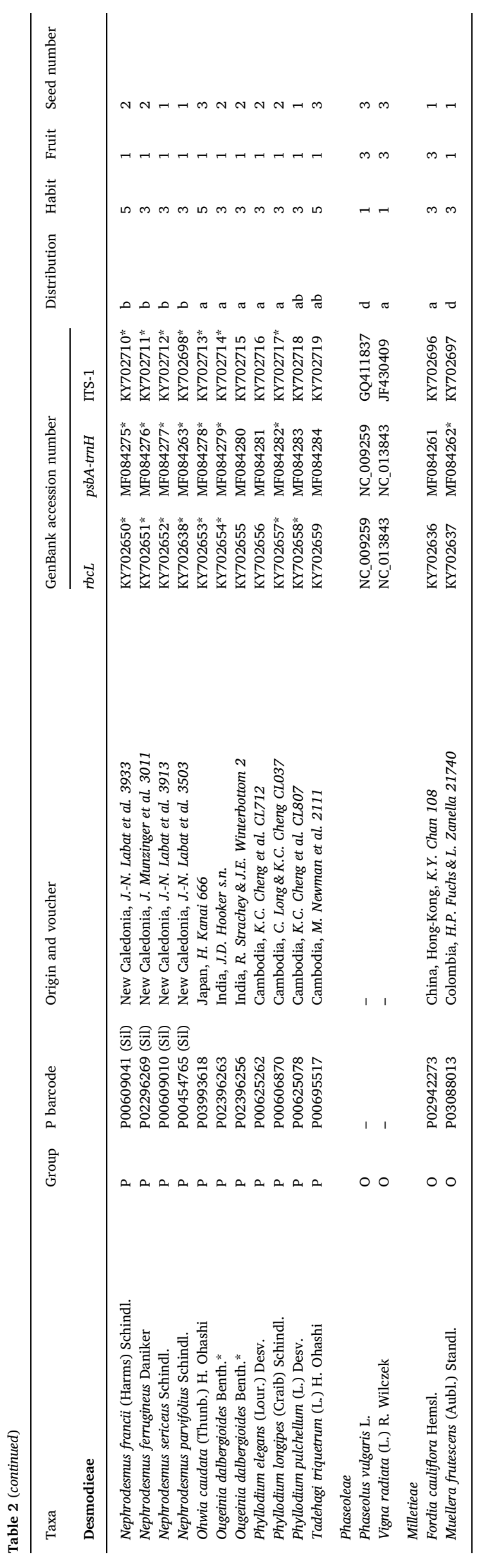

phylogenies published by the Legume Phylogeny Working Group (LPWG, 2013, 2017) showed that the Desmodieae tribe is included within the Indigoferoid/Millettioid clade, together with Phaseoleae sensu lato, Psoraleeae, Abreae, and Indigofereae. Within the phaseoloid Fabaceae, The Desmodieae tribe was strongly supported as monophyletic (for seven of the eight cpDNA markers used; Stefanović et al., 2009), and was sister to Mucuna Adans.

Based on morphological traits, Ohashi et al. (1981) defined three subtribes within the Desmodieae: the Bryinae, the Desmodiinae, and the Lespedezinae. Subsequent molecular analyses placed the Bryinae within the Pterocarpus clade of the Dalbergieae sensu lato (Bailey et al., 1997; Doyle et al., 2000; Lavin et al., 2001). Also, the genera Phyllacium Benn. and Neocollettia Hemsl. were moved from the subtribe Lespedezinae to the tribe Phaseoleae based on morphological, palynological, and molecular evidences (Bailey et al., 1997; Doyle et al., 2000; Kajita et al., 2001). Two subtribes are now recognized within the Desmodieae: the Desmodiinae and Lespedezinae (Ohashi, 2005). The subtribe Desmodiinae shows a higher generic diversity in tropical South and SouthEast Asia (Dy Phon et al., 1994), while the centres of diversity of subtribe Lespedezinae are in temperate East Asia (Huang et al., 2010) and North America (Isely, 1998). The tribe was further circumscribed into three groups based on an analysis of the chloroplast gene $r b c L$ (Kajita et al., 2001; Ohashi, 2005): the Lespedeza group (three genera) corresponding to the Lespedezinae subtribe, and the Phyllodium (12 genera) and Desmodium (17 genera) groups, together corresponding to the Desmodiinae subtribe (Table 1 ).

The Lespedezinae subtribe has been extensively studied during the last decade. Phylogenetic analyses based on cpDNA regions (Kajita et al., 2001; Stefanović et al., 2009; Nemoto et al., 2010) and nuclear ribosomal ITS (Han et al., 2010) strongly supported the monophyly of the Lespedezinae subtribe, including the three genera Lespedeza Michx., Campylotropis Bunge, and Kummerowia Schindl. Campylotropis appeared as the sister group of Kummerowia and Lespedeza. Asia was inferred as the ancestral distribution of the subtribe (Han et al., 2010; Nemoto et al., 2010), and the disjunct distribution of Lespedeza, with eastern Asian and eastern North American species, would be the result of migration through the Bering land bridge during the Miocene (Xu et al., 2012). Later diversification and introgression may have yielded the present species diversity (Xu et al., 2012).

Our aim was to provide a robust phylogeny of the tribe Desmodieae using combined chloroplast ( $r b c L, p s b A-t r n H$ ) and nuclear (ITS-1) sequence data with a large genus sampling including the previously unanalysed genera Hanslia Schindl. and Leptodesmia (Benth) Benth. We also examined ancestral distribution areas and ancestral states for the habit, fruit type and number of seeds per fruit. Special emphasis was placed on the New Caledonian endemic genera Arthroclianthus and Nephrodesmus, for which a substantial sampling was available.

Our results were used to: (1) verify the monophyly of the subtribe Lespedezinae; (2) assess the monophyly of the subtribe Desmodiinae and of each of the two groups defined by Ohashi (2005) within the Desmodiinae; (3) interpret ancestral distribution areas and ancestral states for the habit, fruit type and number of seeds per fruit; (4) specify the phylogenetic relationships of the two endemic New Caledonian genera Arthroclianthus and Nephrodesmus within Desmodiinae; and (5) date their origin in New Caledonia.

\section{Materials and methods}

\subsection{Taxonomic sampling}

The sampling included 25 genera out of the 32 recognized in the tribe (Ohashi, 2005; generic sampling ratio $=78 \%$; Table 1 ). We investigated a total of 58 species of Desmodieae and four outgroup species listed in Table 2. The outgroup species were chosen based on Queiroz et al. (2015): the genera Vigna Savi and Phaseolus L. belong to the Phaseolinae, while Muellera L.f. and Fordia Hemsl. belong to the 
core Millettieae. Leaf material was either silica-dried in the field, in New Caledonia (for some species of Arthroclianthus and Nephrodesmus), or sampled from herbarium specimens preserved at the Paris Herbarium (Muséum national d'Histoire naturelle; code P). Taxa sampled, voucher information, and GenBank accession numbers are listed in Table 2.

\subsection{DNA sequencing}

We analyzed the nuclear ribosomal ITS-1 and two chloroplast regions ( $r b c L$ and $p s b A-t r n H$ ), because these have been used successfully for phylogenetic studies of closely related plants (Shaw et al., 2005), and also for phylogenetic studies within Fabaceae and especially within Papilionoideae (Käss and Wink, 1997; Hu et al., 2002; Han et al., 2010; Nemoto et al., 2010). The chloroplast gene $r b c L$ has been especially used to circumscribe the groups and genera within the Desmodieae tribe (Kajita et al., 2001).

Herbarium or silica-dried leaf material was grounded into powder and total genomic DNA was extracted using the Qiagen DNeasy Plant Mini Kit (Valencia, California, USA). PCR amplifications of the two cpDNA markers ( $r b c L, p s b A$-trnH) and of the nuclear marker ITS-1 were prepared in $20 \mu \mathrm{l}$ including $1 \mu \mathrm{l}$ of non diluted genomic DNA, $2 \mu \mathrm{l}$ of 10x Taq buffer (with $1.5 \mu \mathrm{M}$ of $\mathrm{MgCl}_{2}$ ), $1 \mu$ l of dimethyl sulfoxide $2 \%$ (DMSO), $1 \mu \mathrm{l}$ of bovine serum albumine (BSA), $0.8 \mu \mathrm{l}$ of dNTPs $(6.6 \mathrm{mM}), 0.32 \mu \mathrm{l}$ of each forward and reverse primers, $0.6 \mathrm{U} \mathrm{Taq}$ polymerase (Qiagen), and sterile distilled water.

The following primers were used: $r b c L 1 F$ (5'-ATGTCACCACAAACAGAAAC-3') and $r b c L 724 R$ (5'-TCGCATGTACCTGCAGTAGC$3^{\prime}$ ) for $r b c L$ (Fay et al., 1997); $p s b A$ (5'-GTTATGCATGAACGTAATGCTC$3^{\prime}$ ) and $t r n H^{G U G}$ (5'-CGCGCATGGTGGATTCACAATCC-3') for psbAtrnH ${ }^{G U G}$ (Sang et al., 1997; Tate and Simpson, 2003); ITS1 (5'-TCCGTAGGTGAACCTGCGG-3') and ITS2 (5'-GCTGCGTTCTTCATCGATGC$3^{\prime}$ ) for the nuclear maker ITS-1 (White et al., 1990).

The PCR programs consisted of 35 cycles of 1 min of denaturation at $94^{\circ} \mathrm{C}, 1 \mathrm{~min}$ annealing at $53{ }^{\circ} \mathrm{C}$ for $r b c L, 56^{\circ} \mathrm{C}$ for $p s b A$-trnH and $58{ }^{\circ} \mathrm{C}$ for ITS-1, 2 min extension at $72{ }^{\circ} \mathrm{C}$ and $10 \mathrm{~min}$ final extension at $72{ }^{\circ} \mathrm{C}$. PCR amplifications were performed in a Thermal cycler Biometra. The resulting PCR products were then checked on a $1 \%$ agarose gel with ethidium bromide. The PCR products were sequenced using Sanger sequencing on a 3730xl DNA Analyzer at Genoscope (Centre National de Séquençage, Evry, France).

Forward and reverse sequences were visually edited and assembled using Sequencher v4.9 (Gene Codes Corp., Ann Arbor, Michigan, USA). All newly generated sequences were deposited in GenBank (Table 2).

\subsection{Phylogenetic analyses}

Sequences were automatically aligned in MUSCLE v3.6 (Edgar, 2004) before the alignment was manually revised in BioEdit v.7.2.5 (Hall, 1999). Indels were coded using the simple coding method of Simmons and Ochoterena (2000) in SeqState (Müller, 2005). Both Bayesian inferences (BI) and Maximum Likelihood (ML) analyses were used to estimate phylogenetic relationships. Bayesian inferences were performed using MrBayes v.3.2.5 (Ronquist et al., 2011). For each region, the most adequate model of nucleotide substitution was identified under the Akaike information criterion in MrModelTest v.2.3 (Nylander, 2004): GTR + I + G for ITS-1 and rbcL, and GTR + G for $p s b A$-trnH. For indels, we used the restriction site (binary) model with the option lset coding = variable. Two independent but parallel analyses were conducted using flat priors, starting from random trees and consisting of four chains each. The analyses were run for 5 million generations, sampling every 100 generations and with a $10 \%$ burnin. For comparison, the analyses were also run for 30 million generations, sampling every 1000 generations and with a $25 \%$ burnin. Analysis of output parameters, in Tracer v.1.6 (Rambaut et al., 2014), confirmed the convergence of chains and adequate burnin length. Post-burnin trees were pooled and 50\% majority-rule consensus trees were computed with posterior probability (PP) estimates for all nodes. We ran separate analyses for each region, checked that there was no conflict between the topologies based on the two cpDNA regions, and concatenated the $r b c L$ and $p s b A$-trnH sequences to infer a single topology based on the combined cpDNA dataset. Comparison of the combined cpDNA tree with the nuclear ITS-1 tree, however, revealed supported contradictions (with PP $>0.8$ and bootstrap support (BS) $>70 \%$ ); both datasets were hence not combined. The ML analyses were performed in raxmlGUI 1.5.1 (Silvestro and Michalak, 2012; Stamatakis, 2014), using the same partitions and models of nucleotide evolution as for the BI. We performed 1000 rapid bootstrap replicates and searched for the best-scoring ML tree.

\subsection{Molecular dating}

We implemented an uncorrelated lognormal relaxed clock approach in BEAST v.1.8.1 (Drummond et al., 2012), based on the combined cpDNA dataset. The prior for the ucld.mean parameter was uniform between 0 and 10E100, with an initial value of 1. A Birth-Death process was employed as tree prior, and other parameters were left to default values. Node calibration relied on one fossil and one secondary calibration point. A fossil of a Campylotropis species most similar to the extant C. macrocarpa (Bunge) Rehder was dated to 5.3 Ma (Guo and Zhou, 1992; Xu et al., 2012). We therefore modelled the stem node of $C$. macrocarpa by a uniform prior between 5.3 and $53.0 \mathrm{Ma}$. In addition, the crown node of tribe Desmodieae was dated to ca. 27.0 Ma by Simon et al. (2009). Therefore, we modelled the age of the tribe by a normal distribution with a mean of 27.0 and a standard deviation of $2.0 \mathrm{Ma}$. Two Markov Chain Monte Carlo (MCMC) analyses were run for 50 million generations, and sampled every 2000 generations. Tracer v.1.6 was used to confirm convergence among chains and adequate effective sample sizes (ESS > 200). Both chains were combined using LogCombiner 1.4.8, after discarding the first $10 \%$ generations as burnin. Trees were summarized in a maximum clade credibility tree obtained in TreeAnnotator 1.4.8, and visualized in FigTree 1.1.2 (available at $<$ http://tree.bio.ed.ac.uk/software/figtree/ >).

\subsection{Biogeography and character evolution}

The distribution areas and character states of the extant species were coded according to Ohashi (1973), Kirkbride et al. (2003) and Lewis et al. (2005). We used a Dispersal-Extinction-Cladogenesis model (DEC; Ree and Smith, 2008) implemented in RASP v.3.2 (Yu et al., 2015) to infer ancestral biogeographical areas. Distribution ranges of extant taxa were coded as combinations of four geographic areas: (a) Asia; (b) Oceania; (c) Africa; (d) America. The condensed tree was the maximum clade credibility tree estimated in BEAST, and the maximum number of ancestral areas was not constrained.

To infer the ancestral states for the morphological traits, we used maximum likelihood as implemented in Mesquite v.3.11 (Maddison and Maddison, 2016). Analyses were carried out on the Bayesian cpDNA tree (with 61 tips, after collapsing the branches leading to the two accessions of Ougeinia dalbergioides Benth.), taking into account branch lengths and using the Markov k-state one-parameter model, which is a generalization of the Jukes-Cantor model (Lewis, 2001) and assumes a single rate for all transitions between character states.

The habit was coded using five states (including two combined states), namely: (1) Herb (Fig. 1A); (2) Subshrub (Fig. 1B); (3) Shrub (Fig. 1C) or tree (Fig. 1D); (4) Herb and subshrub; (5) Subshrub and shrub or tree. We defined three categories of fruit types: (1) Indehiscent loment (Fig. 1E-F, J-M); (2) Dehiscent legume (Fig. 1G-I); (3) Indehiscent legume (Fig. $1 \mathrm{~N}$ ). The size of the fruit characterized by the number of seeds in the fruit was coded using three states: (1) small fruit with up to 3 seeds; (2) average-sized fruit with up to 6 seeds; (3) long fruit with up to 7 seeds and more. For the species producing loments, 


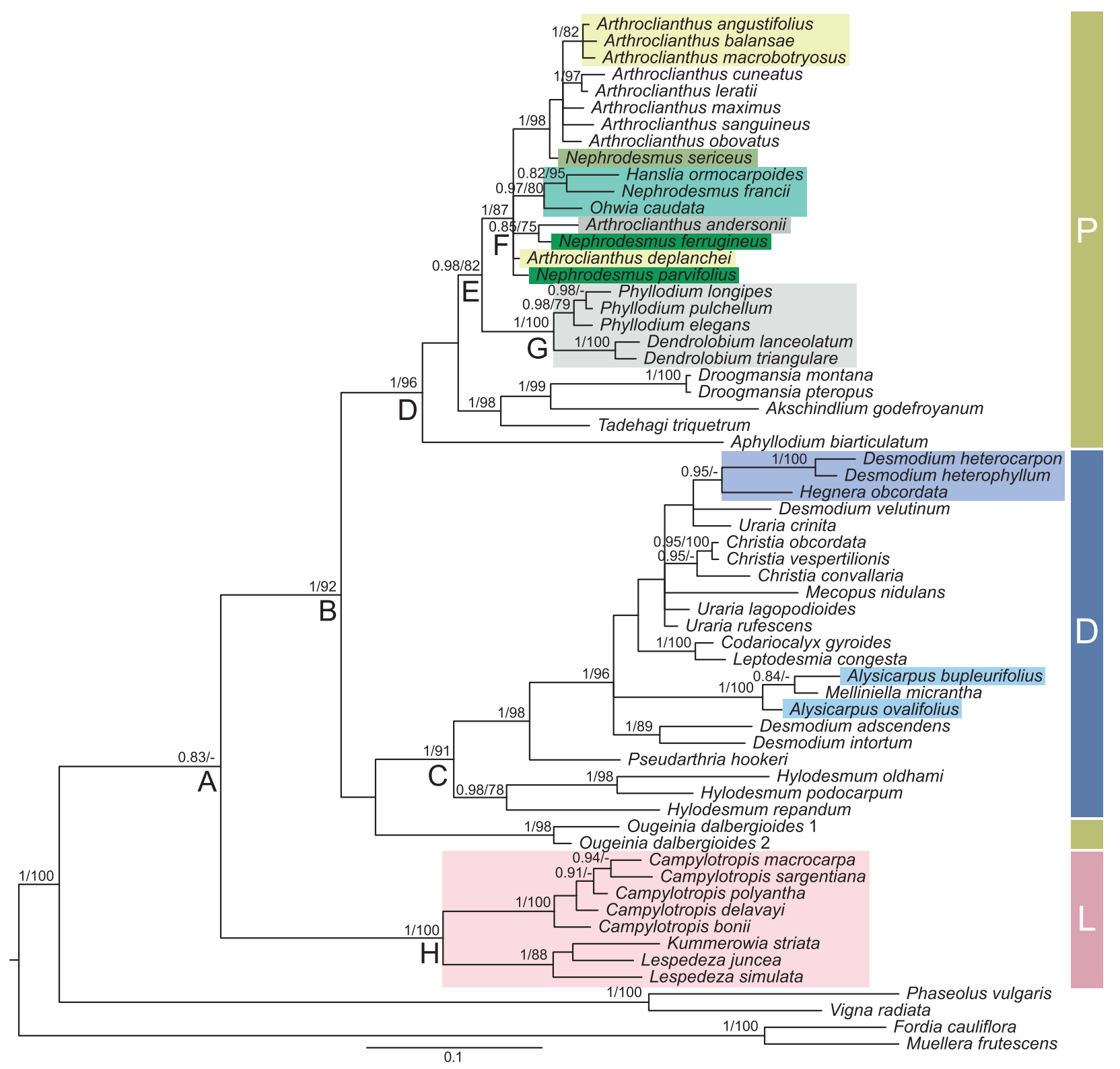

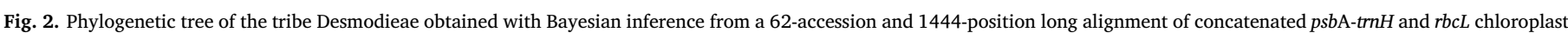

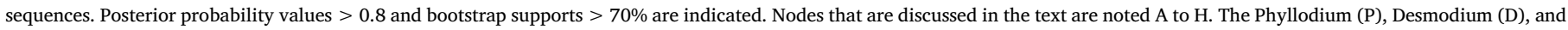

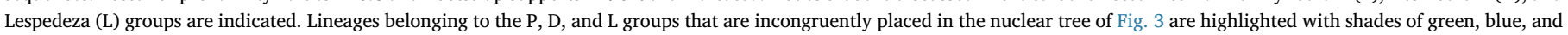
pink, respectively. (For interpretation of the references to color in this figure legend, the reader is referred to the web version of this article.)

this character corresponds to the number of articles. For this last character, personal observations (CS) on herbarium specimens were included in the matrix in order to decrease the number of missing data. The matrix of four characters coded for 61 species (including four outgroup species) is presented in Table 2.

For comparison, we used parsimony in Mesquite to infer the ancestral states for the phenotypic traits (habit, fruit type, and number of seeds in the fruit).

\section{Results}

\subsection{Phylogenetic relationships}

In total, our analyses included 62 species and 180 DNA sequences were newly generated. The ITS-1 alignment was 381-position long and included 100 coded indels, whereas the combined cpDNA alignment was 1444-position long (676 for $r b c L$ and 768 for $p s b A-t r n H$ ) with 117 indels coded. Both BI analyses (5 and 30 million generations) gave identical tree topologies and nearly identical support values (results from the second run are not shown). Topologies of trees obtained from the BI and ML analyses were similar, only differing for groups with low support values. We hence showed the BS values on the tree topology obtained with the BI (Figs. 2 and 3).

Based on the BI using the combined cpDNA dataset, we showed that the tribe Desmodieae is monophyletic (although moderately supported, $\mathrm{PP}=0.83$; Fig. 2), but there was a trichotomy including the two groups of Desmodieae and the Phaseoleae tribe based on ML. Within the tribe, three clades were identified. First, the clade whose crown node is noted $\mathrm{D}(\mathrm{PP}=1, \mathrm{BS}=96 \%$; Fig. 2) partly corresponded to the Phyllodium group and included the genera Arthroclianthus Baill., Nephrodesmus Schindl., Hanslia Schindl., Ohwia H. Ohashi, Phyllodium Desv., Dendrolobium (Wight \& Arn.) Benth., Droogmansia De Wild., Akschindlium H. Ohashi, Tadehagi H. Ohashi, and Aphyllodium (DC.) Gagnep. Second, the clade whose crown node is noted C ( $P P=1, B S=91 \%$; Fig. 2) 


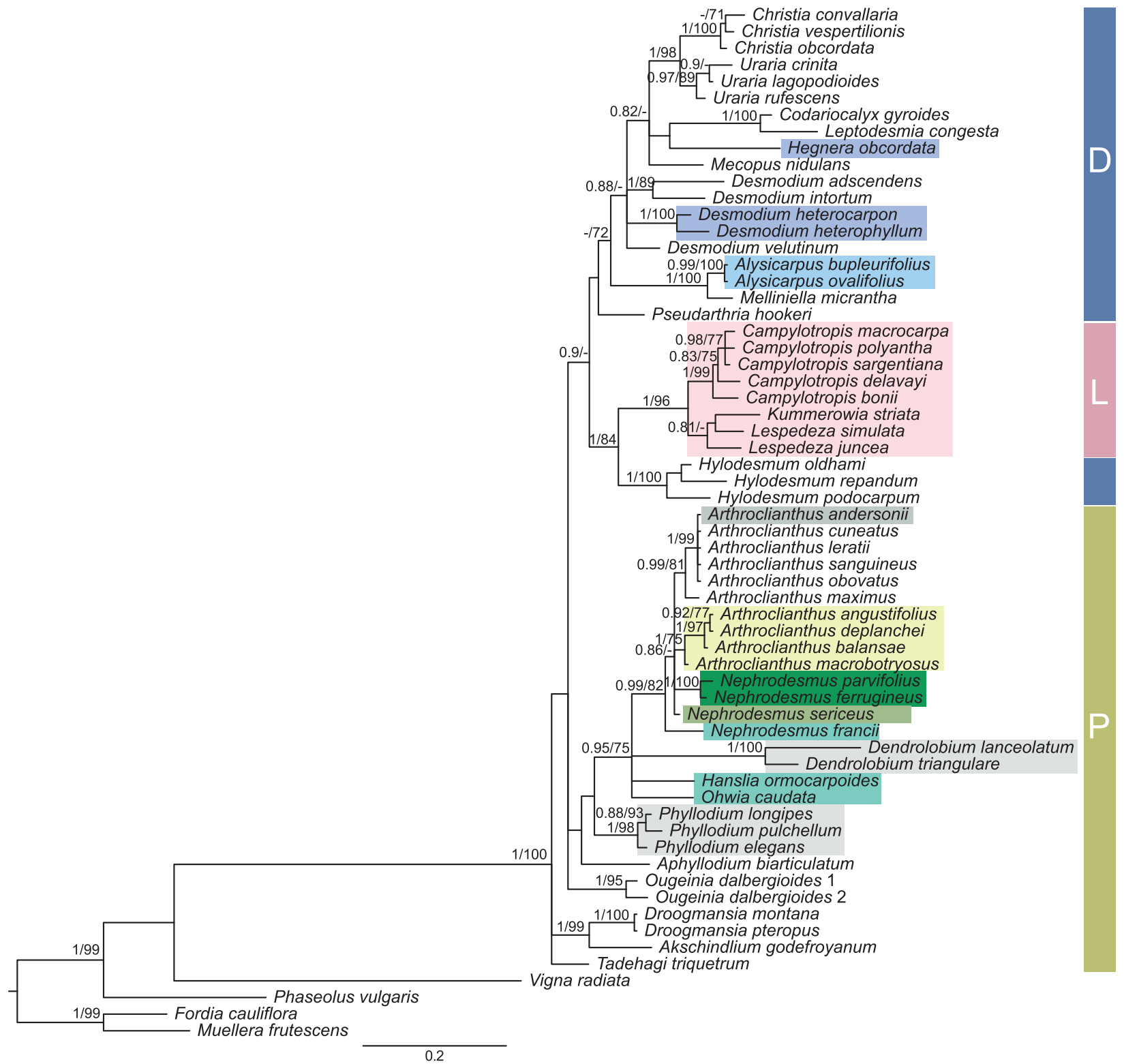

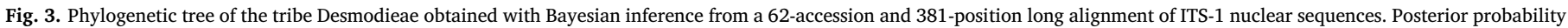

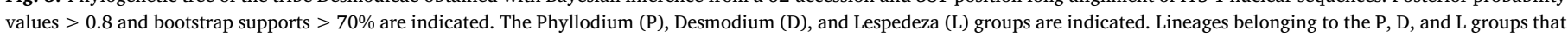

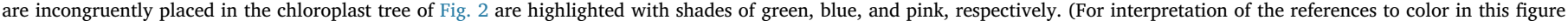
legend, the reader is referred to the web version of this article.)

corresponded to the Desmodium group and was composed of Desmodium Desv., Hegnera Schindl., Uraria Desv., Christia Moench, Mecopus Benn., Codariocalyx Hassk., Leptodesmia (Benth.) Benth., Alysicarpus Neck. ex Desv., Melliniella Harms, Pseudarthria Wight \& Arn., and Hylodesmum H. Ohashi \& R.R. Mill. The genus Ougeinia Benth. in Miquel (belonging to the Phyllodium group) was sister to the Desmodium group but with very low support ( $\mathrm{PP}=0.52$, $\mathrm{BS}=36 \%$; Fig. 2). Third, the group whose crown node is noted $\mathrm{H}$ ( $\mathrm{PP}=1, \mathrm{BS}=100 \%$; Fig. 2) corresponded to the Lespedeza group. It was the earliest diverging of the tribe and included the genera Campylotropis, Kummerowia, and Lespedeza. Clade D was sister to the Desmodium group + Ougeinia, all together being sister to the Lespedeza group. In our sampling, twelve genera were represented by several species, and four of them were nonmonophyletic: Arthroclianthus, Nephrodesmus, Desmodium, and Alysicarpus (Uraria and Lespedeza were also possibly paraphyletic, but the associated support values were low; $\mathrm{PP}=0.76$, BS $=20 \%$ and $\mathrm{PP}=0.77, \mathrm{BS}=68 \%$, respectively). In particular, Arthroclianthus and Nephrodesmus species were intermingled in the phylogeny, and formed a highly supported clade with Hanslia and Ohwia ( $\mathrm{PP}=1, \mathrm{BS}=87 \%$ ).

Based on ITS-1, the monophyly of the tribe Desmodieae was strongly supported ( $\mathrm{PP}=1$, BS $=100 \%$; Fig. 3 ). The Phyllodium group was composed of four lineages, two of which included in the basal trichotomy of the tribe: one consisted of Tadehagi and the other of Akschindlium and Droogmansia (PP $=1$, BS $=99 \%$; Fig. 3 ). The third lineage was the genus Ougeinia, and the fourth clustered most genera of the group with $\mathrm{PP}=0.76$ and $\mathrm{BS}=51 \%$. Ougeinia, the main part of the Phyllodium group and all the remaining genera of Desmodieae formed an unresolved and poorly supported clade (PP $=0.64$, BS $=32 \%$ ). The Desmodium group was paraphyletic since the genus Hylodesmum was sister to the Lespedeza group ( $\mathrm{PP}=1, \mathrm{BS}=84 \%$ ) and Hylodesmum + the Lespedeza group was sister to the remaining genera of the Desmodium group ( $\mathrm{PP}=0.90, \mathrm{BS}=57 \%$ ). Last, the Lespedeza group was retrieved with high support $(\mathrm{PP}=1, \mathrm{BS}=96 \%$ ).

Considering the three groups Phyllodium, Desmodium, and Lespedeza, there was one supported conflict between the cpDNA and ITS-1 topologies involving the position of the Lespedeza group. It was 


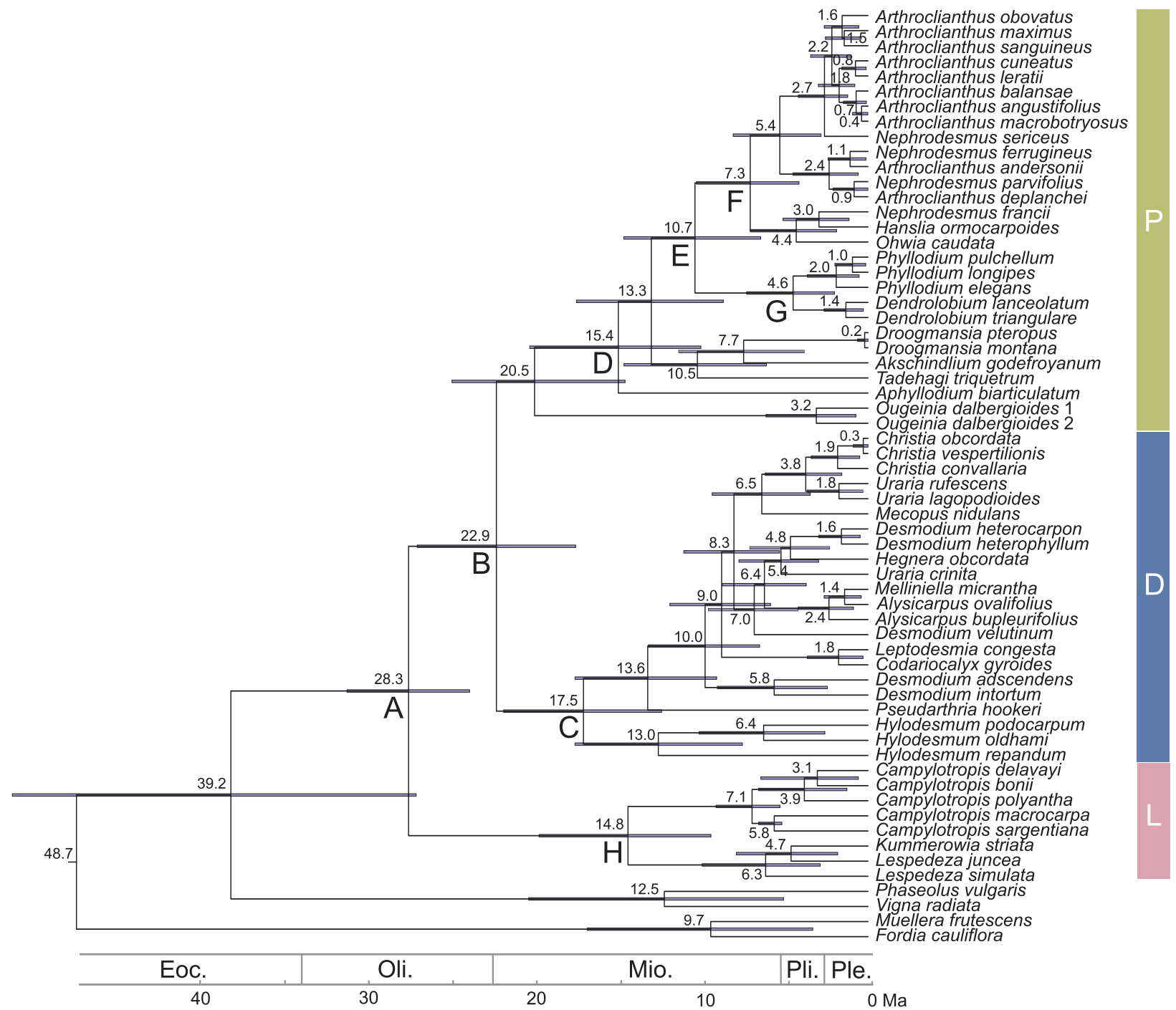

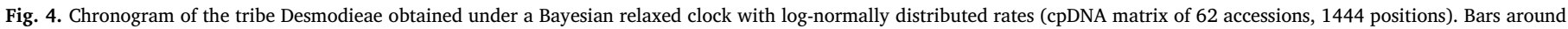

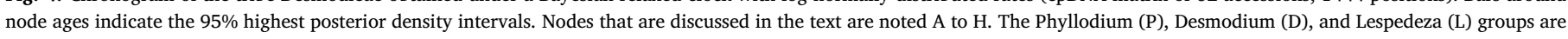
indicated.

retrieved as basal to the tribe and sister group to the groups Phyllodium + Desmodium based on cpDNA, but nested within the Desmodium group and most closely related to genus Hylodesmum based on ITS-1. Within each group, the relationships were similar based on cpDNA and ITS-1, albeit with a few exceptions: (i) in the cpDNA phylogeny, Phyllodium and Dendrolobium were grouped $(\mathrm{PP}=1$, BS $=100 \%)$ and Phyllodium + Dendrolobium was sister to Arthroclianthus + Nephrodesmus + Hanslia + Ohwia with $\mathrm{PP}=0.98$ and BS $=82 \%$ whereas in the ITS-1 phylogeny, Dendrolobium was included in the Arthroclianthus + Nephrodesmus + Hanslia + Ohwia + Dendrolobium clade with PP $=0.95$ and BS $=75 \%$. (ii) Arthroclianthus and Nephrodesmus formed a supported clade based on ITS-1 (PP $=0.99$, BS $=82 \%$ ), whereas they were grouped with Hanslia and Ohwia based on cpDNA ( $\mathrm{PP}=1, \mathrm{BS}=87 \%$ ) because of the position of Nephrodesmus francii (Harms) Schindl. clustering with Hanslia and Ohwia ( $\mathrm{PP}=0.97, \mathrm{BS}=80 \%$ ). Also, the respective non-monophyly of Arthroclianthus and Nephrodesmus relied on a moderate support value in the ITS-1 phylogeny ( $\mathrm{PP}=0.86$, $\mathrm{BS}=63 \%$ ) whereas it was more supported in the cpDNA phylogeny (since $N$. sericeus Schindl. was sister to several Arthroclianthus species with $\mathrm{PP}=1$ and $\mathrm{BS}=98 \%$ ). Last, the relationships among Arthroclianthus and Nephrodesmus samples differed between the cpDNA and ITS-1 topologies, e.g., A. angustifolius
Hochr., A. balansae Schindl., and A. macrobotryosus Hochr. were grouped with $\mathrm{PP}=1$ and BS $=82 \%$ based on the cpDNA, whereas $A$. deplanchei Hochr. appeared more closely related to A. angustifolius and A. balansae than A. macrobotryosus based on ITS-1. (iii) Alysicarpus was monophyletic based on ITS-1 (PP $=0.99$, BS $=100 \%$ ) whereas it was paraphyletic based on cpDNA, but it must be noted that this paraphyly relied on a moderate support value in the cpDNA topology ( $\mathrm{PP}=0.84$, BS $=55 \%$ ). (iv) Hegnera and Desmodium heterocarpon (L.) DC. $+D$. heterophyllum (Willd.) DC. were grouped based on cpDNA (PP $=0.95$, BS $=51 \%$, but not based on ITS-1.

\subsection{Molecular dating}

Our molecular estimations suggest that the tribe Desmodieae started to diversify $28.3 \mathrm{Ma}$ (95\% CI 24.5-32.1 Ma; Fig. 4, crown node A), and that the Phyllodium, Desmodium, and Lespedeza groups started to diversify 20.5 Ma (15.0-25.6 Ma), 17.5 Ma (12.7-22.4 Ma; crown node C), and 14.8 Ma (9.7-20.2 Ma; crown node H), respectively. The clade comprising Arthroclianthus, Nephrodesmus, Ohwia and Hanslia (crown node F) diverged from Phyllodium and Dendrolobium (crown node G) 10.7 Ma (6.6-15.0 Ma) and started to diversify 7.3 Ma (4.3-10.6 Ma). 
Geographical regions

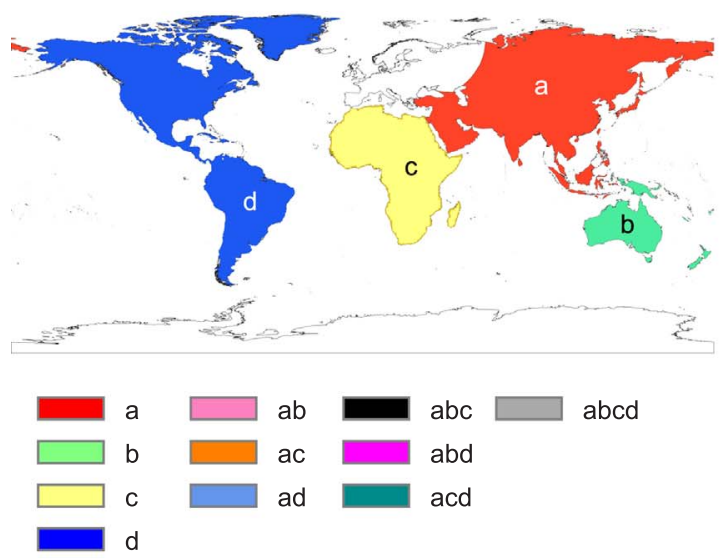

Arthroclianthus obovatus

Arthroclianthus maximus

2 Arthroclianthus sanguineus

Arthroclianthus cuneatus

Arthroclianthus leratii

Arthroclianthus balansae

Arthroclianthus angustifolius

Arthroclianthus macrobotryosus

Nephrodesmus sericeus

Nephrodesmus ferrugineus

F

Arthroclianthus andersonii

Nephrodesmus parvifolius

Arthroclianthus deplanchei

Nephrodesmus francii

- Hanslia ormocarpoides

- Ohwia caudata

Phyllodium pulchellum

- Phyllodium longipes

- Phyllodium elegans

- Dendrolobium lanceolatum

- Dendrolobium triangulare

- Droogmansia pteropus

- Droogmansia montana

- Akschindlium godefroyanum

Tadehagi triquetrum

Aphyllodium biarticulatum

- Ougeinia dalbergioides

- Ougeinia dalbergioides

Christia obcordata

Christia vespertilionis

- Christia convallaria

- Uraria rufescens

- Uraria lagopodioides

- Mecopus nidulans

- Desmodium heterocarpon

Desmodium heterophyllum

Hegnera obcordata

Uraria crinita

Melliniella micrantha

Alysicarpus ovalifolius

- Alysicarpus bupleurifolius

- Desmodium velutinum

- Leptodesmia congesta

Codariocalyx gyroides

- Desmodium adscendens

- Desmodium intortum

Pseudarthria hookeri

- Hylodesmum podocarpum

- Hylodesmum oldhami

- Hylodesmum repandum

- Campylotropis delavayi

- Campylotropis bonii

- Campylotropis polyantha

- Campylotropis macrocarpa

- Campylotropis sargentiana

- Kummerowia striata

- Lespedeza juncea

- Lespedeza simulata

- Phaseolus vulgaris

- Vigna radiata

- Muellera frutescens

- Fordia cauliflora

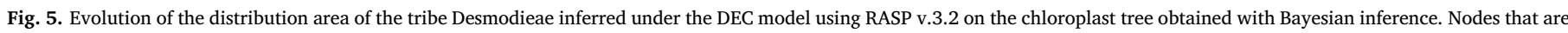

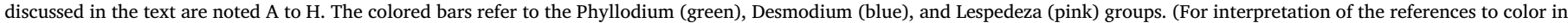
this figure legend, the reader is referred to the web version of this article.) 


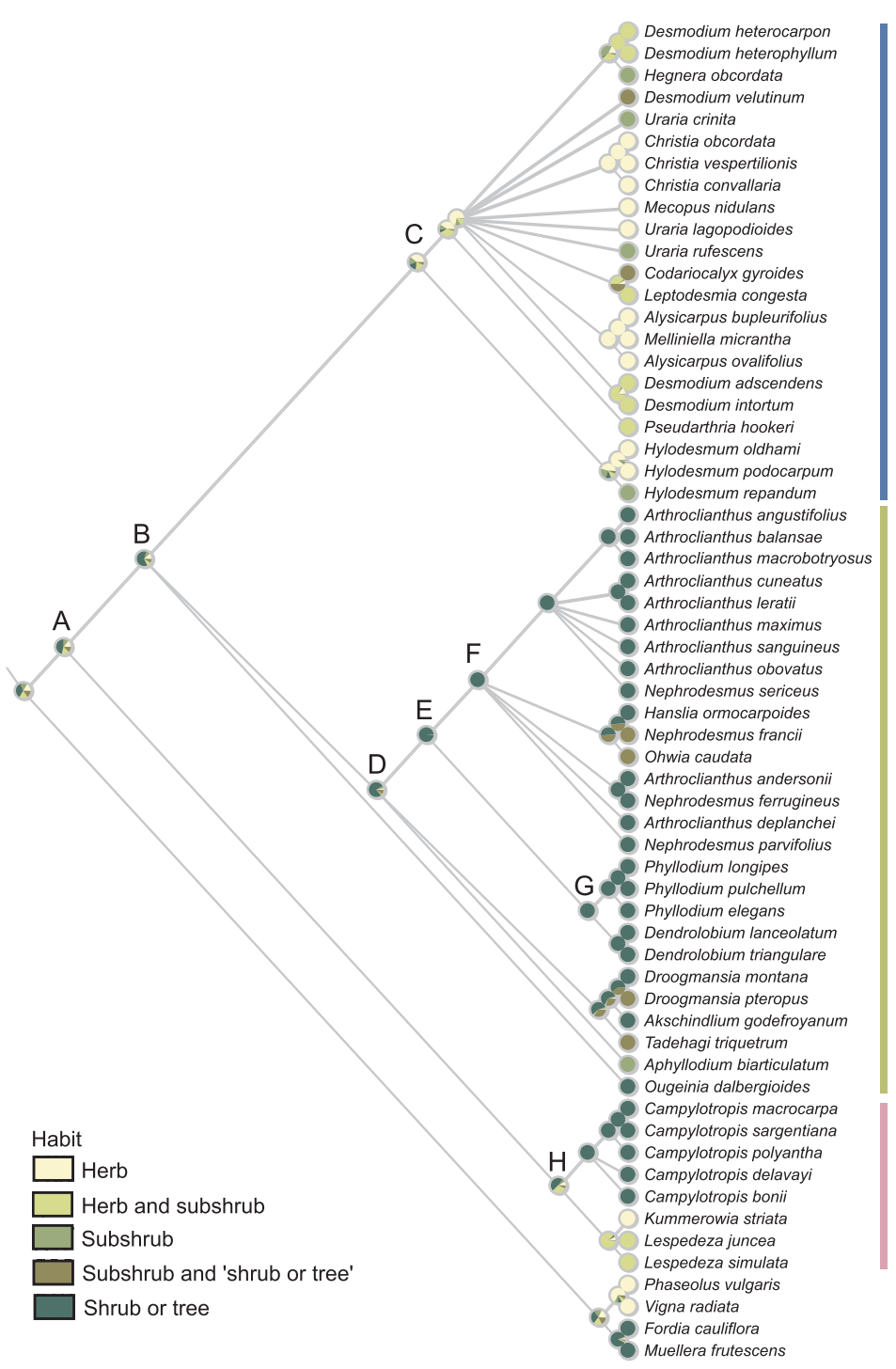

Fig. 6. Evolution of habit in the tribe Desmodieae inferred under maximum likelihood optimization on the 61 -accession tree obtained with Bayesian inference. Nodes that are discussed in the text are noted $\mathrm{A}$ to $\mathrm{H}$. The colored bars refer to the Phyllodium (green), Desmodium (blue), and Lespedeza (pink) groups. (For interpretation of the references to color in this figure legend, the reader is referred to the web version of this article.)

\subsection{Ancestral distribution areas}

The hypothetical ancestor of Desmodieae (crown node A) and of each of the Desmodium (crown node C), Phyllodium excluding Ougeinia (crown node D), and Lespedeza (crown node $\mathrm{H}$ ) groups most likely occurred in Asia (with probabilities of 1, 0.69, 1, and 0.73, respectively; Fig. 5). The Lespedeza clade hosts a single colonization event, from Asia to America, which occurred later than $14.8 \mathrm{Ma}$ and led to the Kummerowia and Lespedeza lineage. In the Phyllodium group, Oceania was probably colonized between ca. 10.7 (node E) and 7.3 Ma (node F), since the most likely ancestral areas were Asia at node $\mathrm{E}$ (probability of 0.82) and Asia + Oceania at node F (1), giving rise to the $A r$ throclianthus, Nephrodesmus, Ohwia and Hanslia lineage. Oceania was colonized three additional times, later than $15.4,10.5$, and $1.0 \mathrm{Ma}$ in the lineages leading to Aphyllodium biarticulatum (L.) Gagnep., Tadehagi triquetrum (L.) H. Ohashi, and Phyllodium pulchellum (L.) Desv., respectively.

The group Phyllodium also hosts a single colonization from Asia to Africa between 10.5 and 7.7 Ma. Within the Desmodium group, the low resolution did not allow inferring a detailed biogeographic scenario, but the results suggested that America was colonized once, giving rise to the Desmodium intortum (Mill.) Urb. and D. adscendens (Sw.) DC. lineage, and that Oceania and Africa were colonized several times.

\subsection{Ancestral states for the habit, fruit type and number of seeds per fruit}

The hypothetical ancestor of Desmodieae (crown node A; Fig. 6) was most likely a shrub or a tree (probability of 0.52). In the Lespedeza group (crown node $\mathrm{H}$ ), the most probable ancestral state was the 'shrub or tree' state (0.51). All Campylotropis retained this ancestral state, while plant size decreased in the genus Lespedeza, and even more in its sister genus Kummerowia (herb).

In the Phyllodium group excluding Ougeinia (crown node D), starting from a most likely 'shrub or tree' state (0.84), a few and slight decreases in plant size (from 'shrub or tree' to 'subshrub or 'shrub or tree") were inferred in the lineages leading to $N$. francii and Ohwia caudata (Thunb.) H. Ohashi, to Droogmansia pteropus (Baker) De Wild. and Tadehagi triquetrum (L.) H. Ohashi, and to Aphyllodium biarticulatum (L.) Gagnep. The ancestor of the Desmodium group (crown node C) was most likely herbaceous (0.49). Several transitions to higher plant sizes (subshrub) occurred in this group. Among these transitions, the state 'subshrub or "shrub or tree" evolved at least once and perhaps twice, in the lineage(s) leading to Desmodium velutinum (Willd.) DC. and Codariocalyx gyroides (Roxb.) Hassk. Ancestral state reconstructions using the parsimony criterion provided similar results (result not shown).

The hypothetical ancestor of Desmodieae (crown node A; Fig. 7) most likely produced indehiscent loments (probability of 0.64; although 

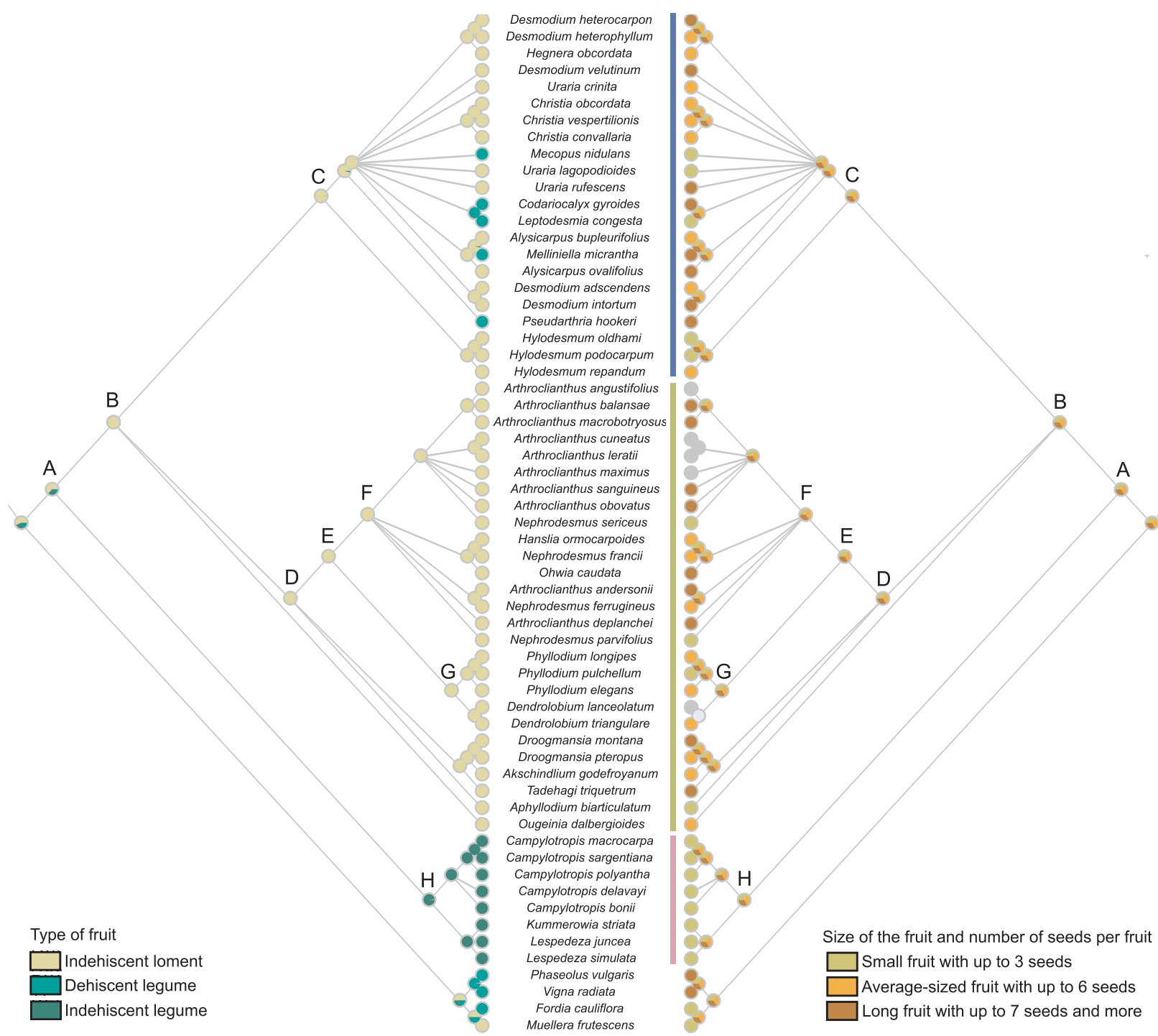

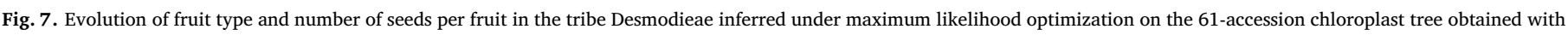

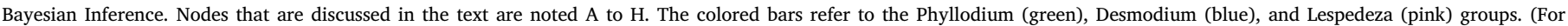
interpretation of the references to color in this figure legend, the reader is referred to the web version of this article.)

this state is ambiguous when using parsimony (result not shown)). Lineages with dehiscent legumes evolved at least three times, exclusively in the Desmodium group. The production of indehiscent legumes is a synapomorphy of the Lespedeza group (Fig. 7).

The ancestral state for the number of seeds in the fruit could neither be inferred unequivocally in the groups Desmodium, Phyllodium excluding Ougeinia (crown node D), and Lespedeza, nor in the tribe Desmodieae as a whole (Fig. 7). The extant lineages included in the Lespedeza group produce indehiscent legumes with up to three seeds.

\section{Discussion}

\subsection{Phylogenetic relationships within Desmodieae}

The monophyly of the tribe Desmodieae was shown in previous studies (Bruneau et al., 1995; Kajita et al., 1996; Doyle et al., 1997; Wojciechowski et al., 2004; Egan et al., 2016; LPWG, 2017), and our analysis confirmed this result based on an unprecedented sampling. Except for the uncertain phylogenetic placement of the genus Ougeinia, the main clades identified on the cpDNA tree correspond to the three groups previously circumscribed based on both morphological and molecular characters in the tribe, i.e. Desmodium, Lespedeza, and
Phyllodium. In addition, we found that the genus Kummerowia is nested within the genus Lespedeza (Figs. 2 and 3), in contrast with the results of Ohashi and Nemoto (2014).

Our sampling included two accessions of $O$. dalbergioides Benth. in order to discard the hypothesis that the uncertain placement of Ougeinia was due to a problem when sequencing the cpDNA markers on the first accession. This monospecific genus was not included in the sampling of LPWG (2017). Regarding the tribe Desmodieae, our results were similar to those shown by LPWG (2017), although the latter study was based on a different taxonomic sampling and on a single chloroplast marker (matK). However, in our study, T. triquetrum, Akschindlium godefroyanum, and Droogmansia formed a clade together with Aphyllodium and the clade gathering the remaining accessions of the Phyllodium group (crown node E), whereas T. triquetrum was sister to all the other members of the Phyllodium group (including T. pseudotriquetrum (DC.) H. Ohashi) in LPWG (2017).

Our dense genus sampling allowed showing several statistically supported conflicts between the chloroplast and nuclear topologies. Similarly, strong differences in the evolutionary history of different cellular compartments have been reported in other plant groups (e.g. Nauheimer et al., 2012; Kramina et al., 2016). Such conflicts can result from reticulate evolution, due to interspecific hybridization. 
Hybridization events in Desmodieae have already been reported in a few studies (e.g. Raveill, 2006; Han et al., 2010; Xu et al., 2017) and hybrid forms (in respect to taxonomically important traits such as fruit form and leaf shape) have been detected when studying herbarium specimens (C. Sarthou, pers. obs.). Other causes of incongruent chloroplast and nuclear tree topologies are incomplete lineage sorting, and particular phylogeographic structure (Rieseberg et al., 1996; Naciri and Linder, 2015). Whether these factors apply to Desmodieae is still hypothetical, and further investigations are needed.

The reconstruction of ancestral states for distribution areas and morphological traits relied on the chloroplast phylogenetic tree of Desmodieae, as the topology was mostly in accordance with the circumscription of infratribal groups as proposed by Ohashi (2005) based on morphological traits, contrary to what was observed on the nuclear tree topology, where the Lespedeza group was nested within the Desmodium group.

\subsection{Biogeography and life history trait evolution in Desmodieae}

The hypothetical common ancestor of Desmodieae most likely occurred in Asia and dates back to the Middle Oligocene, ca. 28.3 Ma. While the ancestral lineages leading to the three major clades likely remained in Asia, several colonization events towards Oceania, America, and Africa occurred later on, within the last 17.5 Ma. They were most probably mediated through long distance dispersal (LDD) events since landmasses had then already diverged for a long time (McLoughlin, 2001), excluding the potential influence of vicariance. Long distance dispersal has been shown to be a common dispersal process in Fabaceae (Lavin et al., 2004), and it is probable that the seeds drifted through ocean currents such as in the tribe Fabeae (Schaefer et al., 2012) and Mucuna (Moura et al., 2016). Nevertheless, the two colonization events from Asia to America in the Desmodium group and in the Lespedeza group occurred less than 10.0 and $14.8 \mathrm{Ma}$, respectively. This was before the Bering Strait got submerged (BrighamGrette, 2001) and dispersal could therefore have been mediated through a land bridge.

Two contrasted trends for the evolution of the habit were identified. In the Phyllodium group excluding Ougeinia, the habit tends to decrease in size, while it increases in some lineages of the Desmodium group. Both colonization events to America (giving rise to L. simulata in the Lespedeza group and to $D$. intortum in the Desmodium group) occurred in lineages presenting herbaceous or shrub habit. The single colonization event of Africa found in the Phyllodium group led to two Droogmansia species that differ by their habit. While Droogmansia montana Jacq.-Fél. retained the likely ancestral state (trees and shrubs), D. pteropus evolved towards lower life forms (trees, shrubs, but also subshrubs). This may be explained by niche competition between sister lineages colonizing the same area.

The type of fruit is a taxonomically useful character to distinguish the species from the Lespedeza group from the other Desmodieae species, as indehiscent legumes are only found in the Lespedeza group. Within the Desmodium group, lineages with dehiscent legumes evolved once or several times from ancestors with indehiscent loments. Furthermore, in the tribe as a whole, only transitions from indehiscence to dehiscence were observed. This may indicate that reduced fruit modularity and dehiscing fruits have been selected during the evolution of Desmodieae, probably because of lower morphogenetic costs and better dispersal abilities.

Indehiscent loments allow for more variability in the number of seeds per fruit than indehiscent legumes (Fig. 7). Evolving from segmented fruits (loments, the ancestral state for Desmodieae) to fruits with a single segment (a synapomorphy of the Lespedeza group) may increase structural constraints during fruit development for ovaries bearing a high number of ovules. This may explain why the Lespedeza lineage consists exclusively of species producing fruits with less than three ovules only. Modularity seems here to allow variability in the number of ovules produced in a single ovary. The dehiscent legume fruit type is apomorphic in the Desmodium group. In this group, when both the degree of fruit segmentation (loment to legume) and the mode of dehiscence (indehiscent to dehiscent) change, the number of seeds is not necessarily low. The mode of dehiscence might hence add a degree of freedom to carpel development in lineages where species producing legumes evolved from ancestors producing loments.

When comparing the evolution of habit and number of seeds per fruit, it seems that more seeds are produced per fruit when plant size is high (except in the Melliniella + Alysicarpus clade). Seed production may thus be linked to the age of the individual (positively correlated with plant height in the case of trees and shrubs) or to adaptations leading to more effective dispersal (Norghauer and Newbery, 2015).

\subsection{The New Caledonian endemic genera Arthroclianthus and Nephrodesmus}

Although the genera Arthroclianthus and Nephrodesmus were circumscribed using morphological characters (but see Ohashi et al. (1981), who noted that Arthroclianthus is scarcely distinct from $\mathrm{Ne}$ phrodesmus), they were not respectively monophyletic based on our molecular data. A taxonomic revision of both genera is hence much needed.

Arthroclianthus and Nephrodesmus either formed a clade, or were grouped together with $H$. ormocarpoides (sister to $N$. francii) and $O$. caudata based on the nuclear and chloroplast datasets, respectively. Oceania was likely colonized between 10.7 and $7.3 \mathrm{Ma}$ by the lineage leading to the common ancestor of Arthroclianthus, Nephrodesmus, Hanslia, and Ohwia (node E in Fig. 5), and the colonization of New Caledonia necessarily occurred either at this time, or later on. This is long after the period of total oceanic submersion of the island shown by geological evidence, which ended ca. 37 Ma (Pelletier, 2007; Nattier et al., 2017), and colonization by an Asian lineage was most likely due to LDD. Such dispersal from Asia to New Caledonia was already shown in other plant groups, e.g., Piper L. (Piperaceae; Smith et al., 2008) and Diospyros L. (Ebenaceae; Turner et al., 2013).

\section{Acknowledgments}

We thank Sovanmoly Hul, Hervé Vandrot, and Joël Jérémie for their help in identifying herbarium specimens. We are grateful to the programs that made our work possible. It was supported by the grant ANR Biodiversité BIONEOCAL, by the ATM 'Taxonomie moléculaire: DNA Barcode et gestion durable des collections' and the network 'Bibliothèque du Vivant' funded by the CNRS, the Muséum national d'Histoire naturelle, the INRA, and the CEA (Genoscope). We thank the Editor and three anonymous reviewers for their constructive comments that greatly improved the manuscript.

\section{References}

Bailey, C.D., Doyle, J.J., Kajita, T., Nemoto, T., Ohashi, H., 1997. The chloroplast $r p l 2$ intron and ORF184 as phylogenetic markers in the legume tribe Desmodieae. Syst. Bot. 22, 133-138.

Brigham-Grette, J., 2001. New perspectives on Beringian Quaternary paleogeography, stratigraphy, and glacial history. Quat. Sci. Rev. 20, 15-24.

Bruneau, A., Doyle, J.L., Doyle, J.J., 1995. Phylogenetic relationships in Phaseoleae: evidence from chloroplast restriction site characters. In: Crisp, M.D., Doyle, J.J. (Eds.), Advances in Legume Systematics, Part 7: Phylogeny. Royal Botanic Gardens, Kew, pp. 309-330.

Doyle, J.J., Doyle, J.L., 1993. Chloroplast DNA phylogeny of the papilionoid legume tribe Phaseoleae. Syst. Bot. 18, 309-327.

Doyle, J.J., Doyle, J.L., Ballenge, J.A., Dickson, E.E., Kajita, T., Ohashi, H., 1997. A phylogeny of the chloroplast gene $r b c L$ in the Leguminosae: taxonomic correlations and insights into the evolution of nodulation. Am. J. Bot. 84, 541-554.

Doyle, J.J., Chappill, A., Bailey, C.D., Kajita, T., 2000. Towards a comprehensive phylogeny of legumes: evidence from $r b c L$ sequences and non-molecular data. In: Herendeen, P.S., Bruneau, A. (Eds.), Advances in Legume Systematics, Part 9. Royal Botanic Gardens, Kew, pp. 1-20.

Drummond, A.J., Suchard, M.A., Xie, D., Rambaut, A., 2012. Bayesian phylogenetics with 
BEAUti and BEAST 1.7. Mol. Biol. Evol. 29, 1969-1973.

Dy Phon, P., Ohashi, H., Vidal, J.E., 1994. Leguminosae (Fabaceae), Papilionoideae, Desmodieae. In: Morat, P.H. (Ed.), Flore du Cambodge du Laos et du Vietnam 27. Muséum national d'Histoire naturelle, Paris, pp. 3-154.

Edgar, R.C., 2004. MUSCLE: multiple sequence alignment with high accuracy and high throughput. Nucl. Acids Res. 32, 1792-1797.

Egan, A.N., Vatanparast, M., Cagle, W., 2016. Parsing polyphyletic Pueraria: delimiting distinct evolutionary lineages through phylogeny. Mol. Phylogenet. Evol. 104, 44-59.

Fay, M.F., Swensen, S.M., Chase, M.W., 1997. Taxonomic affinities of Medusagyne oppositifolia (Medusagynaceae). Kew Bull. 52, 111-120.

Guo, S.X., Zhou, Z.K., 1992. The megafossil legumes from China. In: Herendeen, P.S. Dilcher, D.L. (Eds.), Advances in Legume Systematics, Part 4. Royal Botanic Gardens, Kew, pp. 207-224.

Hall, T.A., 1999. BioEdit: a user-friendly biological sequence alignment editor and analysis program for Windows 95/98/NT. Nucl. Acids Symp. Ser. 41, 95-98.

Han, J.E., Chung, K.H., Nemoto, T., Choi, B.H., 2010. Phylogenetic analysis of eastern Asian and eastern North American disjunct Lespedeza (Fabaceae) inferred from nuclear ribosomal ITS and plastid region sequences. Bot. J. Linn. Soc. 164, 221-235.

Huang, P., Ohashi, H., Iokawa, Y., Nemoto, T., 2010. Fabaceae, tribe desmodieae. In: Wu, C.Y., Raven, P.H., Hong, D.Y. (Eds.), Flora of China, Vol. 10, Science Press, Beijing, and Missouri Botanical Garden, St. Louis, pp. 262-311.

Hu, J.M., Lavin, M., Wojciechowski, M.F., Sanderson, M.J., 2002. Phylogenetic Analysis of nuclear ribosomal ITS/5.8S sequences in the tribe Millettieae (Fabaceae): Poecilanthe-Cyclolobium, the core Millettieae, and the Callerya group. Syst. Bot. 27, 722-733.

Isely, D., 1998. Native and Naturalised Leguminosae (Fabaceae) of the United States (Exclusive of Alaska and Hawai). Iowa State University, Ames, Iowa.

Kajita, T., Ohashi, H., Nemoto, T., Bailey, C.D., Doyle, J.J., 1996. Polyphyly of the legume tribe Desmodieae: evidence from the chloroplast genome. Am. J. Bot. 83, 165-166 (abstract).

Kajita, K., Ohashi, H., Tateishi, Y., Bayley, C.D., Doyle, J.J., 2001. RbcL and Legume phylogeny, with particular reference to Phaseoleae, Millettieae, and allies. Syst. Bot. 26, 515-536.

Käss, E., Wink, M., 1997. Phylogenetic relationships in the Papilionoideae (family Leguminosae) based on nucleotide sequences of cpDNA ( $r b c \mathrm{~L}$ ) and ncDNA (ITS 1 and 2). Mol. Phylogenet. Evol. 8, 65-88.

Kirkbride, J.H., Gunn, C.R., Weitzman, A.L., 2003. Fruits and seeds of genera in the subfamily Faboideae (Fabaceae). U.S. Dep. Agric. Tech. Bull. 1890, 796-797.

Kramina, T.E., Degtjareva, G.V., Samigullin, T.H., Valiejo-Roman, C.M., Kirkbride Jr, J.H., Volis, S., Deng, T., Sokoloff, D.D., 2016. Phylogeny of Lotus (Leguminosae: Loteae): partial incongruence between nrITS, nrETS and plastid markers and biogeographic implications. Taxon 65, 997-1018.

Lavin, M., Pennington, R.T., Klitgaard, B.B., Sprent, J.I., Cavalcante de Lima, H., Gasson, P.E., 2001. The Dalbergioid legumes (Fabaceae): delimitation of a pantropical monophyletic clade. Am. J. Bot. 88, 503-533.

Lavin, M., Schrire, B.P., Lewis, G., Pennington, R.T., Delgado-Salinas, A., Thulin, M., Hughes, C.E., Matos, A.B., Wojciechowski, M.F., 2004. Metacommunity process rather than continental tectonic history better explains geographically structured phylogenies in legumes. Phil. Trans. R. Soc. B: Biol. Sci. 359, 1509-1522.

Lewis, P.O., 2001. A likelihood approach to estimating phylogeny from discrete mor phological character data. Syst. Biol. 50, 913-925.

Lewis, G., Schrire, B., MacKinder, B., Lock, M., 2005. Legumes of the World. Royal Botanic Gardens, Kew.

LPWG (The Legume Phylogeny Working Group), 2013. Legume phylogeny and classification in the 21st century: Progress, prospects and lessons for other species-rich clades. Taxon 62, 217-248.

LPWG (The Legume Phylogeny Working Group), 2017. A new subfamily classification of the Leguminosae based on a taxonomically comprehensive phylogeny. Taxon 66 44-77.

Maddison, W.P., Maddison, D.R., 2016. Mesquite: a modular system for evolutionary analysis. Version 3, 11. < http://mesquiteproject.org > (Accessed 07.03.17).

McLoughlin, S., 2001. The breakup history of Gondwana and its impact on pre-Cenozoic floristic provincialism. Aust. J. Bot. 49, 271-300.

Moura, T.M., Vatanparast, M., Tozzi, A.M., Forest, F., Wilmot-Dear, C.M., Simon, M.F. Mansano, V.F., Kajita, T., Lewis, G.P., 2016. A molecular phylogeny and new infrageneric classification of Mucuna Adans. (Leguminosae-Papilionoideae) including in sights from morphology and hypotheses about biogeography. Int. J. Plant Sci. 177, 76-89.

Müller, K., 2005. SeqState - primer design and sequence statistics for phylogenetic DNA data sets. Appl. Bioinform. 4, 65-69.

Naciri, Y., Linder, H.P., 2015. Species delimitation and relationships: the dance of the seven veils. Taxon 64, 3-16.

Nattier, R., Pellens, R., Robillard, T., Jourdan, H., Legendre, F., Caesar, M., Nel, A., Grandcolas, P., 2017. Updating the phylogenetic dating of New Caledonian biodiversity with a meta-analysis of the available evidence. Sci. Rep. 7, 3705.

Nauheimer, L., Boyce, P.C., Renner, S.S., 2012. Giant taro and its relatives: a phylogeny of the large genus Alocasia (Araceae) sheds light on Miocene floristic exchange in the Malesian region. Mol. Phylogenet. Evol. 63, 43-51.

Nemoto, T., Yokoyama, J., Fukuda, T., Iokawa, Y., Ohashi, H., 2010. Phylogeny of Lespedeza (Leguminosae) based on chloroplast trnL-trnF sequences. J. Jpn. Bot. 85, 213-229.

Norghauer, J.M., Newbery, D.M., 2015. Tree size and fecundity influence ballistic seed dispersal of two dominant mast-fruiting species in a tropical rain forest. For. Ecol. Manage. 338, 100-113.
Nylander, J.A.A., 2004. MrModeltest, Version 2. Program Distributed by the Author Evolutionary Biology Centre, Uppsala University.

Ohashi, H., 1973. The Asiatic species of Desmodium and its allied genera (Leguminosae). Ginkgoana 1, 1-318.

Ohashi, H., Polhill, R.H., Schubert, B.G., 1981. Desmodieae. In: Polhill, R.M., Raven, P.H. (Eds.), Advances in Legume Systematics, Part 1. Royal Botanic Gardens, Kew, pp. 292-300.

Ohashi, H., 2005. Desmodieae. In: Lewis, G., Schrire, B., Mackinder, B., Lock, M. (Eds.), Legumes of the World. Royal Botanic Gardens, Kew, pp. 433-445.

Ohashi, H., Nemoto, T., 2014. A new system of Lespedeza (Leguminosae tribe Desmodieae). J. Jap. Bot. 89, 1-11.

Ohashi, H., Ohashi, K., 2012a. Ototropis, a genus separated from Desmodium (Leguminosae). J. Jap. Bot. 87, 108-118.

Ohashi, H., Ohashi, K., 2012b. Verdesmum, a new genus of Leguminosae: tribe Desmodieae. J. Jap. Bot. 87, 299-306.

Pelletier, B., 2007. Geology of the New Caledonia region and its implications for the study of the New Caledonian biodiversity. In: Payri, C., Richer de Forges, B. (Eds.), Compendium of Marine Species of New Caledonia. Documents Scientifiques et Techniques, vol. II7. Institut de Recherche pour le Développement Nouméa, pp. 19-32.

Polhill, R.M., 1981. Papilionoideae. In: Polhill, R.M., Raven, P.H. (Eds.), Advances in Legume Systematics, Part 1. Royal Botanic Gardens, Kew, pp. 191-208.

Queiroz, L.P., Pastore, J.F.B., Cardoso, D., Snak, C., Lima, A.L.D.C., Gagnon, E., Vatanparast, M., Holland, A.E., Egan, A.N., 2015. A multilocus phylogenetic analysis reveals the monophyly of a recircumscribed papilionoid legume tribe Diocleae with well-supported generic relationships. Mol. Phylogenet. Evol. 90, 1-19.

Rambaut, A., Suchard, M.A., Xie, D., Drummond, A.J., 2014. Tracer, Version 1.6. $<$ http://beast.bio.ed.ac.uk/Tracer > (Accessed 12.12.16).

Raveill, J.A., 2006. Identification of Missouri species of the tribe Desmodieae (Fabaceae) using vegetative characters. Vulpia 5, 14-22.

Ree, R.H., Smith, S.A., 2008. Maximum likelihood inference of geographic range evolution by Dispersal, local Extinction, and Cladogenesis. Syst. Biol. 57, 4-14.

Rieseberg, L.H., Whitton, J., Linder, C.R., 1996. Molecular marker incongruence in plant hybrid zones and phylogenetic trees. Acta Bot. Neerl. 45, 243-262.

Ronquist, F., Teslenko, M., van der Mark, P., Ayres, D., Darling, A., Hohna, S., Larget, B. Liu, L., Suchard, M.A., Huelsenbeck, J.P., 2011. MrBayes 3.2: efficient Bayesian phylogenetic inference and model choice across a large model space. Syst. Biol. 61, 539-542.

Sang, T., Crawford, D.J., Stuessy, T.F., 1997. Chloroplast DNA phylogeny, reticulate evolution and biogeography of Paeonia (Paeoniaceae). Am. J. Bot. 84, 1120-1136.

Schaefer, H., Hechenleitner, P., Santos-Guerra, A., de Sequeira, M.M., Pennington, R.T., Kenicer, G., Carine, M.A., 2012. Systematics, biogeography, and character evolution of the legume tribe Fabeae with special focus on the middle-Atlantic island lineages. BMC Evol. Biol. 12, 250.

Shaw, J., Lickey, E.B., Beck, J.T., Farmer, S.B., Liu, W., Miller, J., Siripun, K.C., Winder, C.T., Schilling, E.E., Small, R.L., 2005. The tortoise and the hare II: relative utility of 21 noncoding chloroplast DNA sequences for phylogenetic analysis. Am. J. Bot. 92, $142-166$.

Silvestro, D., Michalak, I., 2012. RaxmlGUI: a graphical front-end for RAxML. Org. Divers. Evol. 12, 335-337.

Simmons, M.P., Ochoterena, H., 2000. Gaps as characters in sequence-based phylogenetic analyses. Syst. Biol. 49, 369-381.

Simon, M.F., Grether, R., de Queiroz, L.P., Skema, C., Pennington, R.T., Hughes, C.E., 2009. Recent assembly of the Cerrado, a neotropical plant diversity hotspot, by in situ evolution of adaptations to fire. Proc. Natl. Acad. Sci. 106, 20359-20364.

Smith, J.F., Stevens, A.C., Tepe, E.J., Davidson, C., 2008. Placing the origin of two species-rich genera in the Late Cretaceous with later species divergence in the Tertiary: a phylogenetic, biogeographic and molecular dating analysis of Piper and Peperomia (Piperaceae). Plant Syst. Evol. 275, 9-30.

Spjut, R.W., 1994. A systematic treatment of fruit types. Mem. N.Y. Bot. Gard. 70, 1-182.

Stamatakis, A., 2014. RAxML version 8: a tool for phylogenetic analysis and post-analysis of large phylogenies. Bioinformatics 30, 1312-1313.

Stefanović, S., Pfeil, B.E., Palmer, J.D., Doyle, J.J., 2009. Relationships among phaseoloid legumes based on sequences from eight chloroplast regions. Syst. Bot. 34, 115-128.

Tate, J.A., Simpson, B.B., 2003. Paraphyly of Tarasa (Malvaceae) and diverse origins of the polyploid species. Syst. Bot. 28, 723-737.

Turner, B., Paun, O., Munzinger, J., Duangjai, S., Chase, M.W., Samuel, R., 2013. Analyse of amplified fragment length polymorphisms (AFLP) indicate rapid radiation of Diospyros species (Ebenaceae) endemic to New Caledonia. B.M.C. Evol. Biol. 13, 269.

White, T.J., Bruns, T., Lee, S., Taylor, J.W., 1990. Amplification and direct sequencing of fungal ribosomal RNA genes for phylogenetics. In: Innis, M.A., Gelfand, D.H., Sninsky, J.J., White, T.J. (Eds.), PCR Protocols: A Guide to Methods and Applications. Academic Press Inc, New York, pp. 315-322.

Wojciechowski, M.F., Lavin, M., Sanderson, M.J., 2004. A phylogeny of legumes (Leguminosae) based on analysis of the plastid MatK gene resolves many well-supported subclades within the family. Am. J. Bot. 91, 1846-1862.

Xu, B., Wu, N., Gao, X.F., Zhang, L.B., 2012. Analysis of DNA sequences of six chloroplast and nuclear genes suggests incongruence, introgression, and incomplete lineage sorting in the evolution of Lespedeza (Fabaceae). Mol. Phylogenet. Evol. 62, 346-358.

Xu, B., Zeng, X.M., Gao, X.F., Jin, D.P., Zhang, L.B., 2017. ITS non-concerted evolution and rampant hybridization in the legume genus Lespedeza (Fabaceae). Sci. Rep. 7 40057.

Yu, Y., Harris, A.J., Blair, C., He, X., 2015. RASP (reconstruct ancestral state in phylogenies): a tool for historical biogeography. Mol. Phylogenet. Evol. 87, 46-49. 